\title{
"I'm Not Sitting Next To You": Education and Racism in Afro-Mexican Communities
}

DOI: https://doi.org/10.32870/dse.v0i13.228

\section{Cristina V. Masferrer León*}

Translation by Marcela Suárez Essport msuarezessport@gmail.com

To Patricia Méndez, Angustia Torres and all the teachers who fight against racism

\begin{abstract}
Today, the biggest concentration of Afro-Mexican communities is found in the Costa Chica region of Guerrero and Oaxaca, although their presence is also important in other areas and states of Mexico. The social, cultural, economic, and political contributions of Africans and their descendants were significant during the colonial period throughout the territory known today as Mexico. Still, historic processes of racism and discrimination have led to their invisibilization and exclusion.

This paper is a reflection on racism in schools of Afro-Mexican communities in the Costa Chica region. It presents an analysis of interactions between students, showing how bullying reproduces racism in school, as well as the role of teachers in this process, with some confronting the problem and collaborating to eradicate it and others reproducing racist ideas and discriminatory practices. Therefore, although school education promotes learning about discrimination to a certain degree, it also constitutes a space where racism is learned and lived, either in cases of bullying, in discriminatory attitudes by certain teachers, or in official textbooks that deny or minimize the presence and contributions of African descendants in Mexico. Key words: racism, discrimination, education, childhood, African descendants.
\end{abstract}

Classes had ended and students, although ready to go home, continued playing in a schoolyard in Cuajinicuilapa, a town considered as Afro-Mexican ${ }^{1}$ in Guerrero's Costa Chica region of Mexico. Before leaving, Rosa, a fifth grade student, told me a story she knew about "black" and "brown" people. ${ }^{2}$ It is a local story about a shipwreck that is said to have brought the people of African origin who populated the region:

Because I was told that a ship once arrived in front of a small village. The boat arrived and there were many blacks on it. And then one day the ship, the ship sank, it sank and they say that blacks started coming out

*MA in Social Anthropology. Researcher on the Oaxaca team in the National Research Program, "Ethnography of Mexico’s Indigenous Regions”, INAH. Email: cristinamasleon@ gmail.com

1 Afro-Mexican is a term used in the Oaxaca and Guerrero state constitutions; it refers to historically settled Mexican populations who are descendants of African men and women who were victims of the slave trade from the 16th to the 19th century (See: Conapred, 2011).

2 "Black" and "moreno" [alternately translated in this article as "brown", "dark skinned", or left in the original Spanish] are the principal terms used to name this population in the Costa Chica region. Both words have been used since the Viceroyalty period (1521- 1810). Several organizations and individuals from the Costa Chica region in Oaxaca and Guerrero prefer the terms "black community" and "black Afro-Mexican". 
from the ship one by one. And they say that they came to the village, got married and had children, and grew to be more and more (Rosa, interview, 2012).

Rosa explained to me that the "black" people married the "brown" [moreno] people because the "white" ones wouldn't marry them. I then asked her how she could tell if someone is moreno, to which she answered - as if it were obvious - "because they are brown". I insisted: "and what if you can't see? If you close your eyes and can't see, how can you tell if someone is brown?" "By asking them", she answered. As if it were a game, I asked her to imagine she could not see nor talk, but she could hear. I thought she would mention the people's way of talking, as in this region it is usually seen as a characteristic feature. Instead, Rosa closed her eyes and after a moment she said, "I can hear one of them saying, 'I'm not sitting next to you because you are brown"' (Interview, 2012).

Rosa's expressions reflect her ideas concerning Afro-Mexicans, as well as her experiences regarding discrimination of people considered to be black or brown. The decision to sit or not to sit next to someone based on the person's ethnic identity or on one's perception of the color of the person's skin, or the "race" imposed on him or her, and the fact of saying as much to the person, is one of the ways in which racism and discrimination emerge in the school contexts to which Rosa and other children are used to.

This type of racist practice reminds me of the experience of a black woman from the Costa Chica region, who after many years of living in the city of Oaxaca had to face this kind of incident on a bus - some people preferred to remain standing instead of sitting next to her (personal communication, 2015). If we go a little further, we can remember what happened in a distant context of space and time. In 1955, in the United States, Rosa Parks refused to give up her seat to a white man, at a time when racism in that country was so extreme that Afro-Americans or black people had to seat in the back of the bus, leaving the seats in front for whites. These are extremely different historical, social and political contexts, but in both cases what lies behind racist practices is the perception of "the other" as inferior and the subsequent determination to reject his or her company. Thus the choice of who to sit or not to sit with is not a light matter, but rather one that can become embedded as one of the racist experiences that children and adults face in daily life.

The aim of this paper is to reflect on racism and racist discrimination in school spaces in the Costa Chica region of Guerrero and Oaxaca. I begin with the relationships between students to show how bullying in schools occurs as a form of reproduction of racism. Next, I describe experiences of racism and discrimination in school that show the participation of some teachers in these processes, despite the fact that there are others who fight against discrimination. This study is the result of field work carried out in different communities in the Costa Chica region, mainly in the

3 Human races do not exist in biological terms (Lewontin, 1972). In this article therefore I understand "race" and "racial" as a social, historical, ideological and political construction that imagines or invents the existence of races and imposes this category on persons and populations, despite the fact that they do not correspond to any biological reality (Hoffmann, 2008). 
municipalities of Cuajinicuilapa and Santa María Huazolotitlán from 2011 to 2013. I used methods and techniques such as ethnography, educational ethnography and interviews with children and adults. I also ran workshops for educators as well as radio and painting workshops for children (see Masferrer, 2014b).

It is important to point out that on many occasions there are teachers, principals, parents, and children who try to avoid these kinds of practices, although other teachers, family members and children practice and reproduce racism. Thus, in no way do I seek to reduce the social actors I worked with to the racist situations in which they were involved. On the contrary, my interest is to reveal the complexity of these painful experiences that undermine the human rights, dignity and self-esteem of girls, boys, women and men. The Afro-Mexican or black communities in the Costa Chica region possess a significant cultural and historic heritage, such that their cultural wealth and diversity are not restricted to the experiences of racism and discrimination that they face and which they themselves are trying to eradicate. Thus, the purpose of drawing attention to this issue is to contribute to its understanding and elimination.

\section{The Costa Chica: the context of the research}

The region known as the Costa Chica is a strip of Mexico's Pacific coast that extends approximately from Acapulco in the state of Guerrero to Huatulco in the state of Oaxaca. The region hosts Afro-Mexican and indigenous (mainly Mixteco, Chatino, Amuzgo, Tlapaneco and Nahua) communities as well as people who do not consider themselves to be part of any of those groups. Today, the biggest Afro-Mexican settlement is located in the Costa Chica region (CDI, 2012; INEGI 2015). Nonetheless, it is important to mention that historically, African and African descendant populations spread throughout Mexican territory during the Viceroyalty period and after Independence. Moreover, the economic, social, cultural and political contributions of the thousands of persons of African descent have been extremely meaningful in the construction of Mexico.

Data from the National Institute of Statistics and Geography's [INEGI] recent census [Encuesta Intercensal 2015] shows that in Mexico there are 1.4 million persons who consider themselves to be African descendants. The highest numbers are found in Guerrero and Oaxaca, albeit with significant numbers in other states such as Veracruz, Mexico State and Mexico City (INEGI, 2015). In 2013 INEGI also published "A Socio-demographic Profile of Communities with Afro-Mexican Populations in Oaxaca", with information concerning 106 communities that are considered to have Afro-Mexican populations (INEGI, 2013).

Besides this demographic aspect, there are several NGO's which have been striving for the empowerment of the Afro-Mexican population since the 1990's, fighting discrimination and endeavoring to obtain constitutional recognition in the federal sphere. Some of these non-profit organizations are México Negro AC, AFRICA AC, Taller Cultural Cimarrón, EPOCA AC, ECOSTA, Yutu Cuii SSS; Red de Mujeres Afromexicanas AC, Asociación de Mujeres de la Costa de Oaxaca AC, and Socpinda DH AC, among others. 
In the words of the current president of Mexico Negro AC, Sergio Peñaloza, discrimination was "the principal element that sparked this process of struggle, and along the way we have found many things, like the rescue of our culture, which have helped to make visible what was denied to blacks, and all of this led later to constitutional recognition" (Interview, 2012).

\section{Background}

Historical and anthropological scholarship on racism in Mexico has focused on indigenous and migrant populations (Castellanos and Sandoval, 1998; Castellanos. 2000 and 2003; Gómez, 1991 and 2005; París, 1999; Urias, 2007; Yankelevich, 2009; Gall, 2004). Research concerning how racism is expressed in policies of intercultural education as well as in curricula, programs and textbooks has also been carried out (Molina, 1995; Gnade, 2008; Aguilar, 2012; Baronnet, 2013; Ballesteros, 2014; Gallardo, 2014; Barquín, 2015; Velasco, 2016). In this area, the most notable studies address this problematic among indigenous populations, occasionally associated with migration or the debasement of native languages in the scholastic context (Barrón, 2008; Martínez Buenabad, 2008; Coronado y Mena, 2010).

In contrast, school racism in relation to Afro-Mexican populations has received much less attention. In previous works I have described how elementary and telesecundaria - rural schoolhouses centered on pre-recorded lessons - textbooks issued by the Department of Public Education [SEP] reproduce racist ideas and stereotypes through content that refers to human diversity in terms of race and that deny or minimize the contributions of African descendants (Masferrer, $2011 \mathrm{y}$ 2014a). Other studies have referred to the reproduction of this type of ideas regarding indigenous people (Molina, 1995; Gnade, 2008) based on analyses of educational materials previous to the Comprehensive Reform of Basic Education (RIEB). ${ }^{4}$

Post-RIEB educational material produced by the Department of Education is mandatory in every school in the country. It tends to categorize Africans and African descendants as "blacks" and "slaves", without providing opportunities for an appreciation of the heterogeneity of African cultures throughout history and throughout Americas, in particular in Mexico (Masferrer, $2011 \mathrm{y}$ 2014a). In this vein I have analyzed the experiences of educators and students in the Costa Chica region in relation to these contents in order to go beyond the analysis of textbooks to shed light on racist and discriminatory practices (Masferrer, 2014b in press). Thus this paper seeks to broaden the discussion regarding the experiences of racism and discrimination in school contexts with significant Afro-Mexican populations.

4 The RIEB (Comprehensive Reform of Basic Education) started in 2004 at the preschool level, continued in 2006 with middle school and was finally applied to elementary schools between 2009 and 2011 (See: Gallardo, 2014). 


\section{Conceptual notes: prejudice, stereotype, racism and racist discrimination}

According to Allport (1954:9), ethnic prejudice is an attitude of contempt based on an imperfect and inflexible generalization that may be expressed or simply felt; it may be addressed to a group in general or to an individual belonging to that group. This attitude is nurtured by stereotypes; that is, generalizations or over-generalizations in relation to a group (Plous 2003: 1). According to Eduardo Restrepo (2012:179), it involves prefabricated images or ideas projected onto a group of persons "whose characteristics and behavior are in general erroneously caricaturized" (2012: 179).

Discrimination is related to prejudices and stereotypes, despite the fact that these are different phenomena, since discrimination is a behavior that implies treating certain persons in a different way, putting them at a disadvantage that in some way restricts their rights (CNDH, 2012: 6). I use Jesús Rodríguez' definition of discrimination as a "systematic, culturally defined, socially extensive conduct of contempt against a person or group of persons on the basis of a negative prejudice or stigma related to an undeserved disadvantage, the effects of which (whether intentional or not) harm the person's or group's fundamental rights and liberties" (Rodríguez, 2008: 26).

Something to be emphasized in this way of understanding discrimination is that it is systematic behavior, culturally and historically defined, with consequences which are often, but not necessarily, intentional. This point is fundamental in the task of analyzing racism and discrimination in a manner that transcends guilt and instead revolves around raising awareness and sensibility regarding its complex motives and effects.

According to anthropologist Eduardo Restrepo (2012: 176), discrimination "entails the twofold articulation of an act of differentiation and an exercise of exclusion". Therefore, it is important to examine the different criteria employed to categorize persons, as well as the way in which those considered different are excluded. The main forms of exclusion are rejection, denial and neglect, all of which can be limited to thoughts or expressed through specific conducts.

Racism, in turn, is an ideological, political and doctrinal phenomenon that implies a set of practices and behaviors among persons and groups that take the form of prejudices, stereotypes, segregation, exclusion and discrimination (Wieviorka, 2009: 51-52). Although it has been biologically proven that races do not exist (Lewontin, 1972; Ramírez, 2007 and 2009), researchers such as Wieviorka (2009: 13) point out that racism characterizes "humans grouped according to natural attributes, associated at the same time with intellectual and moral characteristics, applicable to each individual related to this group", which in turn gives rise to degrading and exclusionary practices" (2009: 13).

One can thus consider racism as a form of discrimination articulated around the notion of race, as claimed by Eduardo Restrepo (2012: 177). Nevertheless, in this article I use the term racist discrimination - instead of racial discrimination - in order to highlight the inexistence of races, the artificiality of racial categories, and the link between this form of discrimination and racism. 


\section{"To feel bad": definitions of discrimination in school and everyday life}

For fifth and sixth grade boys and girls at an elementary school on Oaxaca's Costa Chica region, discrimination refers to insults and nicknames that some children use for others that make them "feel bad". Boys and girls who participated in a collective interview in 2013 considered these types of practices as negative. In the words of $5^{\text {th }}$ grader Frida Tejada, "discrimination is bad because you are showing that you don't have values or equality" (Interview, 2013).

According to these students, approximately 10-12 years old, someone is discriminated based on a physical disability, the "color" of his or her skin, his or her "race", his or her way of being, how he or she talks, whether he or she stutters, his or her economic situation, how he or she dresses, or if he or she is "chubby" or "skinny". Any of these factors is enough to make others start teasing or giving nicknames. For example, there is a girl called "broken tooth" because she has a chipped tooth; a boy called "heron beak" because he has thick lips; there is a girl who some call "fat witch" and a boy who is mocked because his feet are very big. Thus skin color, "race", and ethnic origin are not the only reasons for mocking, although the children mentioned cases of this type as well, with nicknames such as "burnt tortilla", "little black Bimbo" or "dirty foot indian".

The Department of Education's (SEP) "Civic and Ethical Development" textbooks for grades 1 to 6 address discrimination, but they do not offer enough tools or strategies to facilitate its understanding nor to raise student awareness of its importance. These books take note of discrimination based on sex, gender, and diversity, but discrimination based on skin color or race is only mentioned briefly. Further, none of the books explain that races of humans do not exist in biological terms.

In the Civic and Ethical Development textbook for $6^{\text {th }}$ grade, discrimination is defined as differentiating, excluding or restricting the rights of other persons on the basis of "social or national origin, language, religion, age, disabilities, physical appearance, gender identity or sexual orientation, that is, any feature that identifies the person" (Álvarez et al., 2011b: 55). A similar definition appears in the fifth grade textbook on the same subject: "To discriminate means to give undeserved treatment to another person or groups because they are different". According to the textbook, one can be discriminated for thinking differently, dressing differently, practicing a different religion, having a different skin color or coming from another town, city or country. The book also explains that mistreating persons does not only refer to "seeing them with contempt", but also includes "denying them the right to be who they are or preventing them from having the same opportunities and services as everybody else... to discriminate is to not respect every person's way of being and thinking and thus infringe on their rights" (Álvarez et al., 2011a: 63).

When comparing the children's responses with the textbook definitions of discrimination, we can see that school education has an influence on the notions they develop concerning discrimination, but the descriptions they gave of the phenomenon are not centered on being deprived of a

5 The Mexican baked goods company Bimbo had a product called "Negrito" (little black boy), which is now called "Nito". 
right, but rather on verbal aggressions among peers. This shows one of the ways in which the definitions of discrimination used in scientific and legal spheres are translated into daily life behavior by boys and girls in a particular context.

\section{Experiencing racism and racist discrimination in school}

Education and freedom from discrimination are childhood rights. Therefore it is important for the school to have an atmosphere of respect and equal treatment for boys and girls, especially considering that school is a space provided by the government. However, discrimination persists in school spaces in the Costa Chica region. Patricia Mendez, member of México Negro AC and elementary school principal and teacher in Guerrero explains this as follows:

\footnotetext{
Yes, there is discrimination here. My colleagues and I can see the way in which they (the children) are discriminated, not only by the other children but also by some of the teachers themselves. If a child is dark skinned and comes from a low-income family, he or she is discriminated more... they seat him or her apart and don’t pay him or her any attention (Patricia Mendez, interview 2012).
}

In addition, in forums where Afro-Mexicans participate it is common to hear about experiences of children who have been excluded from the group that carries the Mexican flag in school ceremonies, in spite of having obtained the best grades and even the best average in their group. These testimonies have been made in public, with tearful eyes and trembling voices, reflecting how painful this act of discrimination and exclusion can be.

Likewise, in two of the workshops that I have run with educators from the Costa Chica region, principals and teachers have insisted that their black pupils are less intelligent and lazier that the others (Masferrer, 2014a, in press). These kinds of ideas have their origin in the pseudo-scientific racism of the eighteenth, nineteenth and twentieth centuries, which set forth allegedly scientific bases to explain the differences between human "races", establishing a hierarchy among them and assigning to each one a certain fixed capacity of intelligence, physical strength or moral characteristics (Velázquez e Iturralde, 2012: 90-91). Although it has been shown that these beliefs lack all scientific credibility, it is disturbing that they continue to circulate among educators and school authorities, given that they can easily translate into discriminatory behavior towards children and adolescents, which would severely affect their educational processes.

According to the Convention on the Rights of the Child, education should favor the development of "the personality, aptitudes and physical and mental capacity of the child, to the maximum of his/her possibilities...Children should be inculcated with respect for their parents, their cultural identity, their language, their values, the national values of the country they live in, and the values of their country of origin as well as those of civilizations other than their own" (UNICEF). Thus, we must ask ourselves to what extent the above-mentioned injunctions are honored in a school atmo- 
sphere where comments or offenses on the basis of ethnic origin and physical appearance are common. Official textbooks present a biased version of history, making no reference to the contributions of the thousands of Africans and African descendants towards the construction of Mexico, nor mentioning the Afro-Mexicans who are currently part of this country (Masferrer, 2011 and 2014a).

Bullying or school harassment can be a very strong, violent experience for children, capable of damaging their right to education and freedom from discrimination. Therefore verbal aggressions among peers should not be dismissed as merely part and parcel of daily humor and normal school experiences, because, more than an individual action, bullying related to racism is part of a culturally and historically based practice that is systematic and socially pervasive, matching Rodríguez Zepeda's (2008) definition of discrimination.

The boy I am going to talk about next did not abandon his education but had to move to a different school. Like other children, he went to first grade in an elementary school in an AfroMexican town on the coast of Oaxaca. The children there used to abuse him physically often by hitting him. His mother talked to the teacher, but she did not respond, so the problem continued. The teacher claimed that the boy was hit when she was not around, during recess for example, so she was not aware of it. Seeing that the physical and verbal aggressions continued, the mother decided to send the child to another school in a nearby town, a single room school house with two groups, where each teacher was responsible for three classes in three different grades (Field diary, 2013).

I asked why her son was being bullied and she explained that it was because he is "very dark skinned" and added "...I know that I am black but I don't want people to come around telling me that; in any case we are all from the black race here, here everyone is dark skinned" (Field diary, 2013). She explained to her son that he should not feel bad because of his skin color, that he has that color because she is dark skinned and his father is güero [light skinned]. ${ }^{6}$ She even tells him not to feel bad because his little brother "is the most light skinned in the school", she said. The younger brother was next to her when she said this and objected that there were other children as light skinned as him in his school, but the mother insisted that he was the most light skinned. As can be seen in this case, experiences of racist discrimination in school are connected to what occurs inside the family as well, where exclusion does not necessarily take place but differences in skin color are pointed out. ${ }^{7}$

Experiences of discrimination based on skin color are not exclusive to elementary school. They can also take place in preschool. A woman named Guadalupe recalled how her daughter was bullied in preschool "because she is dark skinned". One day after leaving her daughter at school she overheard a group of girls saying they should not befriend her daughter. She was very upset and asked the girls why they were saying that. The girls answered, "because she's black and we're

6 In some Mexican contexts the word "güero" [translated throughout as "light skinned"] refers to people with blonde hair and light skin. In the Costa Chica region this term refers to people with a lighter skin color than most of the other people in the region, even if they don't have blonde hair.

7 For an analysis on racial socialization in the family see: Correa, 2013. 
light skinned" (Interview 2013). She spoke strongly to the girls and went to her daughter's teacher for an intervention.

Guadalupe was so upset that she told the girls "so you think because you're light skinned...? Who cares? No matter how light skinned you are, you are ugly for what you do, my daughter might be ugly but no matter how she may look, she is pretty to me". Guadalupe thinks that her daughter "would like to not be dark skinned, but at least I tell her, I'm not upset that my children are dark skinned" (Interview 2013). These reactions show an internalized racism in the girl as much as in the mother, by suggesting that being dark skinned is something negative and associated with ugliness. The fact of being black or dark skinned has become an issue for the girl, who has asked her mother why she is dark skinned while her mother is light skinned. Guadalupe explains to the girl that it is because her father and her aunt are dark skinned, and, "more than anything, because of the sun" (Interview 2013).

In April 2013 Guadalupe's daughter and other classmates participated in a class dance presentation during an important public ceremony in their town. The preschool teachers covered the children's faces, legs and arms with a black substance, as they considered the children's skin was not dark enough to represent the "black Afro-Mexican" community. They danced two pieces: Francisco Gabilondo Soler's "El Negrito Bailarín" [The Little Black Dancer] and Celia Cruz's "La Negra Tiene Tumbao" [The Black Girl has Rhythm]. Both pieces emphasize the supposed disposition of black people for music, dance, laziness and sexuality - all stereotypes that have historically been negatively associated with African descendants. Furthermore, painting the children's bodies black might reinforce the stereotype that Afro-Mexican or black people can be reduced to somatic features, as well as meaningfully mark the children, who had the experience literally inscribed onto their bodies. During the presentation something else stood out very strongly: all the children had been painted black except for Guadalupe's daughter.

Regarding this anecdote it is important to emphasize that these preschool teachers in no way intentionally participated in an act of racism or discrimination. On the contrary, they were trying to participate in an event where the Afro-Mexican and black population were being celebrated. One of them explained that since some of the girls had "white" skin they decided to paint them so they could represent the blacks; she didn't seem to notice that the only girl they didn't paint is the one I have referred to. In this sense, it is important to remember that discrimination is defined according to its consequences and not necessarily according to intentionality. Thus, Philomena Essed (1991: 39) explains that from a macro point of view, racism is a system of structural inequalities and a historical process, created and recreated by means of routine practices, while from a micro perspective it consists of a set of practices in line with the macro structures of racial inequality, the consequences of which may or may not be intentional.

Fighting against discrimination, on the other hand, requires an intentional effort and even training. Angustia Torres, a teacher with fifteen years of experience and member of the civil orga- 
nization AFRICA, told me that a few years ago she had a student who was bullied for being black. The child went to her and asked if God loved everybody in the same way; "if he did then why did he give white skin to some, and to me, he sent me here all burnt, smoked, so that the other children make fun of me and don't want to play with me" (Angustia Torres, Interview 2013). Professor Torres acknowledged that "this is a tremendous form of discrimination, because, whether you like it or not, you grow with it and it hurts; I noticed that this child after a few months became somewhat violent" (Interview, 2013). After being part of AFRICA for many years, she is well acquainted with discrimination, which enables her to approach children and their families to head off these kinds of situations.

According to the testimony by Angustia Torres, the boy "was a target of mockery; they didn't even call him by his name"; his classmates would call him "sorullo"8 or say "here comes "black choco", don't talk to him". Choco is a word used in the region for "dirty". Certain contents of SEP (Department of Education) textbooks reproduce ideas that associate black with dirtiness, negativity and ugliness. Paradoxically, the following example comes from the fifth grade textbook of the subject Civic and Ethical Development.

One of the pages of this book shows a drawing of a black naked man sitting passively in a tub with water in front of a fully-clothed white man who is kneeling near the tub. Above this image is the following text of Aesop's fable "The Black Man":

A man bought a black slave who he thought was black due to lack of care, that he had never taken a bath since he became a slave, so he started bathing and washing him every day; he scrubbed him constantly with soap but the black man wouldn't lose his color, his blackness, and instead got sick and died. This fable teaches us that nobody can change the way someone else was born (Álvarez et al., 2011a: 62).

This text reduces blacks to slavery and servitude: "A man bought a black slave". No attention is given to his ethnic background; for this SEP textbook the man is not Wolof or Mandinga, nor an African or an African descendent: he is simply "a black man". The man doesn't seem to be able to make any decisions for himself, but rather is portrayed as unresponsive and inactive before the decisions of the man who "bought" him. The "black man" gets sick and dies due to this passivity. As if this weren't enough, blackness is associated with dirtiness, unpleasantness, and negativity: "who he thought was black due to lack of care, that he had never taken a bath since he became a slave".

The moral of this fable is not related to addressing discrimination but rather says that the way in which one is born cannot be changed. The book seems to suggest that the man was born with an inability to wash or make decisions for himself, eventually dying as a result. Thus the idea that "he

8 According to the Royal Academy of the Spanish Language (RAE) dictionary, "soruyo" is an "ill-formed and poor quality tobacco". However, the term might derive or be related to the word "zurullo" which refers to excrement (http://dle.rae.es). 
was born to be a slave" is reproduced. ${ }^{9}$ It is necessary to make it clear that this might not have been the sense of the fable for Aesop, a Greek philosopher from the $6^{\text {th }}$ century B.C., who reportedly was enslaved and later released. The analysis of this fable would require consideration of Aesop's life. However, the book does not provide any information in that respect, so the reader is left with what is written there. It is also important to remember that slavery was associated with African populations only after the $15^{\text {th }}$ century, with the establishment of the transatlantic slave trade. Before that, slavery did not necessarily involve Africans or African descendants (Velázquez and Iturralde, 2012). This consideration, without a doubt, changes the reading and interpretation of the fable, but such information is not made available to teachers or students.

This paper focuses on racist discrimination towards boys and girls considered to be black or brown. Nonetheless, indigenous and Afro-Mexican groups not only share the space they live in but also many experiences with racism and discrimination as well as social and economic conditions of inequality. Hermenegildo Albino, teacher at a school in the Costa Chica region, pointed out: "As most of the people here are dark skinned or black, I saw a small boy who was discriminated by the other children who told him "you're just an indian (Interview, 2013)". I have also heard that some children use the word "choco" to refer to indigenous people ("choco indian").

As I will show next, discrimination towards indigenous and Afro-Mexican children in the region may share characteristics with other acts of discrimination which are similarly unfair and in violation of human rights, but are perceived in a milder fashion by the actors involved. I was in a fifth grade classroom of a school in the Costa Chica region when a student sat next to me and confided, "everybody discriminates me here because I am light skinned". He then added that this was why he remained in the classroom during recess. This boy had arrived recently from a city in the north of Mexico, so that his condition of migrant compounded the perceived difference of his skin color. I told him, "but there is nothing wrong with being light skinned", to which he quickly answered, "I know", I immediately realized that my reaction had been absurd, not only for this particular boy but also for those who had previously told me that they were being discriminated for being black or brown and to whom I had answered in a similar way.

This boy knows and feels that being light skinned is not a setback. The color of his skin is not the problem. I even heard him on other occasions making negative comments about black or brown peers (Field notes, 2012). This boy does not like to be bullied and there is no doubt that this kind of discrimination - as he himself correctly calls it - affects him, but when he affirms that he is mistreated "for being light skinned" he doesn't feel insulted in any way. He knows and feels that there is nothing wrong with him, which is why he replied, "I know" to my absurd response. In contrast,

9 Classic Greek philosophers such as Aristotle stated that some men were born to be enslaved and others to be masters: "nature... as a means of conservation, has created some beings to give orders and others to obey" (Saco, 2000:230). These ideas were reproduced in subsequent centuries, for example Palacios Rubios in the 16th century indicated that some men "seem to be born to command and dominate, while others are so rough and obtuse that they seem destined to obey and serve"; "from the very moment of their conception some are masters and some are serfs, there is then a natural tendency towards the existence of masters and slaves" (Moreno,2003:49-50). 
even when I make vain attempts to make other children who are being bullied for being black feel better about themselves, I achieve nothing more than a reiteration that they do not like the color of their skin. They feel and think that there is something wrong with them.

This form of discrimination is a twofold articulation of differentiation and exclusion, but while this boy is convinced that there is nothing wrong with the color of his skin, those who suffer discrimination because of the dark tone of their skin do believe that there is something wrong with them. It is from here that we can understand the difference between a kind of bullying that is part of a racist structure, and other types of harassment in school. This is due to the manner in which racist discrimination has been historically configured in Mexico and other countries. As Plous (2003; 1922) explains, people who are the object of stereotypes can come to think of themselves in terms of those stereotypes.

Eduardo Restrepo (2012: 179) calls this brand of internalized racism "endoracism", arguing that "racism is not only directed to other individuals or groups, but can be directed to oneself as an individual or collectivity". In this way, people may reject their own cultural practices, reproduce racist stereotypes about themselves or other members of their community, or wish they had a skin color different from their own or to the one associated to the group they belong to. In this regard, dark skin color is not a negative attribute in and of itself, yet historically and socially it has been constructed as such. Only in this regard can it be considered a "stigma" (Goffman, 2006).

\section{Final thoughts}

Racism is learned, lived, reproduced and contested in school. According to Van Dijk (1988), schools reproduce racism by means of discourse and various forms of communication such as textbooks, teacher lessons, conversations and other kinds of social interactions. I believe that actors participate in discriminatory actions "when they form, adapt, transmit and share relevant social cognitions concerning their own group as well as minority groups" (Van Dijk, 1988: 134-135). As I have shown here, bullying has precisely this effect on girls and boys in school contexts, as it is a way of forming, adapting, transmitting and sharing racist prejudices and stereotypes.

For children in the Costa Chica region, discrimination means insulting or bullying others for some reason, including the "race" which others are considered to belong to. In contrast, legal and scientific definitions of discrimination tend to emphasize the deprivation of some right. It is interesting to consider the way in which children construct these concepts from their everyday experiences, especially taking into consideration the relevance of the school education of which they form part.

Although children tend to highlight negative comments or insults related to skin color, experiences of racist discrimination in school contexts certainly are not limited in this respect. School education in the Costa Chica region plays an important role in the reproduction of racism, as most of the teachers understand human diversity from a racial perspective, while others express openly 
racist opinions about black or brown people, repeating stereotypes about their intelligence, strength and sexuality (Masferrer, in press). Certain educators treat students differently according to the color of their skin, or ignore bullying among peers for the same reason. Fortunately, there are also teachers concerned about racist discrimination who try to deal with these cases, in many occasions in collaboration with black or Afro-Mexican organizations in the region. In contrast, the Mexican state has not undertaken any action to eradicate racist discrimination from school contexts, nor has it modified its textbooks, despite ample efforts and communications with SEP authorities. ${ }^{10}$

The cases of racist discrimination presented here show the twofold articulation of differentiation and exclusion referred to by Eduardo Restrepo in his studies on racism. One of the criteria to differentiate people is "race", a term that in this region is associated with skin color and other phenotypical features such as hair, but that is also related to family and geographic and ethnic background (Masferrer, 2014b). Rosa, whom I referred to at the beginning of this article, expresses ideas about black history but also reflects on the discrimination she observes and lives in her daily life when she says that she imagines she can tell if a child is dark skinned because another child tells him or her, "I'm not sitting next to you because you are dark skinned".

\section{Bibliography}

Aguilar Nery, Jesús (2012). "Diferencia racial en docentes de educación básica de Tijuana y Tecate. Un estudio exploratorio". In: Culturales, vol. 8, núm. 15, enero-junio. Mexico: Universidad Autónoma de Baja California, pp. 47-80.

Allport, Gordon (1954). The nature of prejudice. Cambridge: Addison-Wesley Publishing Company.

Álvarez Lilian, Patricia Ávila, Bulmaro Reyes, Valentina Cantón, Adriana Corona, Esther Juárez and Norma Romero (2011 a). Formación cívica y ética. Quinto grado. Mexico: SEP (ciclo escolar 2012-2013).

(2011 b). Formación cívica y ética. Sexto grado. Mexico: SEP (ciclo escolar 2012-2013).

Ballesteros Páez, María Dolores (2014). "El presente del pasado y la construcción de identidad(es). Continuidades y cambios en la producción de los libros de texto de Historia de México de Educación Secundaria (1993-2012)", doctoral thesis in Social Science. Monterrey: Tecnológico de Monterrey.

Baronnet, Bruno (2013). "Racismo y discriminaciones en el sistema educativo mexicano". In: Ascencio, Gabriel (coord.). Teoría y práctica de la educación intercultural en Chiapas. Mexico: UNAM, pp. 63-79.

10 In 2012, 2013, 2014 and 2015, María Elisa Velázquez, Gabriela Iturralde and the author of this article have been in communication with SEP authorities regarding the modification of mandatory textbooks. However, up to this moment the meetings held and documents presented have had no effect. In general, excuses are made in terms of lack of resources, institutional bureaucracy and frequent changes of personnel. 
Barquín Cendejas, Alfonso (2015). Antropología y poder político. El ejercicio de poder en las políticas de educación intercultural. Mexico: INAH.

Barrón Pastor, Juan Carlos (2008). "Promoviendo relaciones interculturales. Racismo y acción afirmativa en México para indígenas en Educación Superior". In: Trace, núm. 53. Mexico: CEMCA, pp. 22-35.

Castellanos Guerrero, Alicia and Juan Manuel Sandoval (coords.) (1998). Nación, racismo e identidad. Mexico: Nuestro Tiempo.

Castellanos Guerrero, Alicia (2000). "Antropología y racismo en México”. In: Desacatos, núm. 4. Mexico: CIESAS, pp. 1-28. (coord.) (2003). Imágenes del racismo en México. Mexico: UAM/Plaza y Valdés.

Comisión Nacional de los Derechos Humanos (CNDH) (2012). La discriminación y el derecho a la no discriminación. Mexico: CNDH.

Comisión Nacional para el Desarrollo de los Pueblos Indígenas (CDI) (2012). Informe final de la consulta para la identificación de comunidades afrodescendientes de México. CDI, Mexico.

Consejo Nacional para Prevenir la Discriminación (Conapred) (2011). Guía para la acción pública de la población afrodescendiente en México. Mexico: Conapred.

Coronado, Marcela and Patricia Mena (coords.) (2010). Lengua y cultura en procesos educativos: investigaciones en Oaxaca. Oaxaca: UPN.

Essed, Philomena (1991). Understanding Everyday Racism. An interdisciplinary Theory. California: Sage Publications.

Gall, Olivia (2004). "Identidad, exclusión y racismo: reflexiones teóricas y sobre México". In: Revista Mexicana de Sociología, año 66, núm. 2, abril-junio. Mexico: UNAM, pp. 221-259.

Gallardo Gutiérrez, Ana Laura (2014). "Racismo y discriminación en el sistema educativo mexicano: claves desde las reformas a la educación básica nacional en el siglo XXI (2006 y 2011)", doctoral thesis in Pedagogy. Mexico: UNAM.

Gnade, Jill Renee (2008). "Raza, racismo y educación escolar en México", doctoral thesis in LatinAmerican Studies. Mexico: UNAM.

Goffman, Erving (2006). Estigma. La identidad deteriorada. Buenos Aires: Amorrortu.

Gómez Izquierdo, Jorge (1991). El movimiento antichino en México (1871-1934). Problemas del racismo y del nacionalismo durante la Revolución Mexicana. Mexico: INAH. (coord.) (2005). Los caminos del racismo en México. Mexico: Plaza y Valdés.

Hoffmann, Odile (2008). "Entre etnicización y racialización: los avatares de la identificación entre los afrodescendientes en México". In: Castellanos, Alicia (coord.), Racismo e identidades. Sudáfrica y afrodescendientes en las Américas. Mexico: UAM, pp. 163-176.

Instituto Nacional de Estadística y Geografía (INEGI). (2013). Perfil sociodemográfico de localidades con presencia de población afromexicana de Oaxaca, Mexico: INEGI.

— (2015). Encuesta Intercensal 2015, Mexico: INEGI. Available at www.inegi.org.mx/est/contenidos/Proyectos/encuestas/hogares/especiales/ei2015 
Lewontin, Richard (1972). The Apportionment of Human Diversity. In: Journal of Evolutionary Biology, vol. 6, pp. 381-398.

Martínez Buenabad, Elizabeth (2008). “Análisis de las relaciones interétnicas. Niños indígenas migrantes desde una escuela periférica de la ciudad de Puebla", doctoral thesis, Mexico: CIESAS.

Masferrer León, Cristina (2011). "La enseñanza sobre los africanos y afrodescendientes en la educación primaria y secundaria de México". In: Afrodescendencia. Aproximaciones contemporáneas de América Latina y el Caribe, Centro de Información de las Naciones Unidas para México, Cuba y República Dominicana, pp. 150-157.

(2014a). "Racismo, ignorancia y olvido. La esclavitud y las personas de origen africano en la educación primaria y secundaria de México". In: Serna, Jesús and Fernando Cruz (comps.). Afroindoamérica. Resistencia, visibilidad y respeto a la diferencia. Mexico: UNAM, pp. 141158.

(2014b). "Aquí antes se llamaba Poza Verde. Conocimientos de niños de la Costa Chica sobre su pueblo y lo negro, tesis de maestría en Antropología Social”. Mexico: CIESAS.

(in printing) "La afrodescendencia en la educación básica de México: libros de texto nacionales y prácticas docentes locales". In: Cottias, Myriam, Marie-Albane de Suremain and Eric Mesnard, Enseigner les traites, les esclavages, leurs abolitions et leurs heritages. Paris: Karthala.

Molina Ludy, Virginia, (1995). "La ideología subyacente en la discriminación hacia los pueblos indios”. In: Barceló, Raquel, María Portal and Martha Sánchez (coords.), Diversidad étnica y conflicto en América Latina. El indio como metáfora en la identidad nacional. Vol. II. Mexico: UNAM, Plaza y Valdés, pp. 147-174.

Moreno Núñez, Paula (2003). "La esclavitud: sus formas, tipologías y tipos en la historia de México y el mundo", thesis in Etnohistory. Mexico: ENAH.

París Pombo, María Dolores (1999). Racismo y nacionalismo: la construcción de identidades excluyentes. In: Política y cultural, núm. 12. Mexico: UAM, pp. 53-76.

Plous, S. (2003). The Psychology of Prejudice, Stereotyping and Discrimination: An Overview, (pp. 1-25), retrieved on May 152014 from www.simplypsychology.org/Prejudice.pdf. (Originally published in S. Plous (ed.), Understanding Prejudice and Discrimination. New York: McGraw-Hill, pp. 3-48).

Ramírez, Carlos (2007). "De genes, razas y racismo" (parte I). In: Revista del Instituto Nacional de Higiene Rafael Rangel, vol. 38, núm. 2, diciembre. Caracas: INHRR, pp. 64-65.

— (2009). "De genes, razas y racismo" (parte II). In: Revista del Instituto Nacional de Higiene Rafael Rangel, vol. 40, núm. 1, enero. Caracas: INHRR, pp. 64-68.

Restrepo, Eduardo (2012). Intervenciones en teoría cultural. Popayán: Universidad del Cauca. Rodríguez Zepeda, Jesús (2008). Un marco teórico para la discriminación. Mexico: CONAPRED. Saco, José Antonio (2002). Historia de la esclavitud. Cuba: Imagen Contemporánea. 
Urías Horcasitas, Beatriz (2007). Historias secretas del racismo en México, 1920-1950. Mexico: Tusquets.

UNICEF. Convención sobre los Derechos del Niño. Retrieved on May 152014 from www.unicef. org/mexico/spanish/mx_resources_textocdn.pdf

Velasco Cruz, Saúl (2016). "Racismo y educación en México". In: Revista Mexicana de Ciencias Políticas y Sociales, año LXI, núm. 226. Mexico: UNAM, pp. 379-408.

Wieviorka, Michel (2009). El racismo: una introducción. Barcelona: Gedisa.

Yankelevich, Pablo (coord.) (2009). Nación y extranjería. La exclusión racial en las políticas migratorias de Argentina, Brasil, Cuba y México. Mexico: UNAM.

Van Dijk, Teun (1988). "El discurso y la reproducción del racismo". In: Lenguaje en contexto, núm. 1. Buenos Aires: Universidad de Buenos Aires, pp. 131-180.

Velázquez, María Elisa y Gabriela Iturralde (2012). Afrodescendientes en México. Historias contra el olvido y la discriminación. Mexico: CONAPRED. 